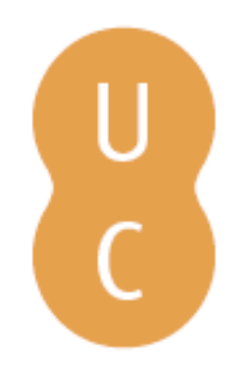

\title{
pompalina
}

\section{Rate of spread in coupled models: fireline curvature and pyrogenic potential}

Autor(es): $\quad$ Thomas, C. M.; Sharples, J. J.; Hilton, J. E; Evans, J. P.

Publicado por: Imprensa da Universidade de Coimbra

URL

persistente: URI:http://hdl.handle.net/10316.2/44706

DOI: $\quad$ DOI:https://doi.org/10.14195/978-989-26-16-506_188

Accessed : $\quad$ 26-Apr-2023 00:23:31

A navegação consulta e descarregamento dos títulos inseridos nas Bibliotecas Digitais UC Digitalis, UC Pombalina e UC Impactum, pressupõem a aceitação plena e sem reservas dos Termos e Condições de Uso destas Bibliotecas Digitais, disponíveis em https://digitalis.uc.pt/pt-pt/termos.

Conforme exposto nos referidos Termos e Condições de Uso, o descarregamento de títulos de acesso restrito requer uma licença válida de autorização devendo o utilizador aceder ao(s) documento(s) a partir de um endereço de IP da instituição detentora da supramencionada licença.

Ao utilizador é apenas permitido o descarregamento para uso pessoal, pelo que o emprego do(s) título(s) descarregado(s) para outro fim, designadamente comercial, carece de autorização do respetivo autor ou editor da obra.

Na medida em que todas as obras da UC Digitalis se encontram protegidas pelo Código do Direito de Autor e Direitos Conexos e demais legislação aplicável, toda a cópia, parcial ou total, deste documento, nos casos em que é legalmente admitida, deverá conter ou fazer-se acompanhar por este aviso. 


\section{ADVANCES IN}

\section{FOREST FIRE RESEARCH}

\section{8}

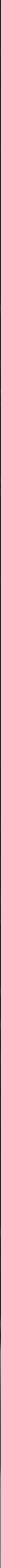


Short contribution - Decision Support Systems and Tools

Rate of spread in coupled models: fireline curvature and pyrogenic potential

\author{
C.M. Thomas ${ }^{1 *}$; J.J. Sharples ${ }^{1}$; J.E. Hilton ${ }^{2}$; J.P. Evans ${ }^{3}$ \\ ${ }^{1}$ Applied and Industrial Mathematics Research Group, School of Physical, Environmental and \\ Mathematical Sciences, UNSW, Canberra, ACT 2600, Australia, \{christopherthomas@cmt.id.au*\} \\ ${ }^{2}$ Data61, CSIRO, Clayton South, VIC 3169, Australia \\ ${ }^{3}$ Climate Change Research Centre and ARC Centre of Excellence for Climate System Science, UNSW, \\ Sydney, NSW 2052, Australia
}

Keywords: Dynamic fire behaviour, fire-spread models, curvature, coupled atmosphere-fire modelling, pyrogenic potential

\title{
1. Introduction
}

The inclusion of curvature-dependent rate of spread has been proposed as a computationally efficient way of improving simple fire-spread models. Such a technique has been used to model the behaviour of laboratory-scale junction fires (Sharples et al. 2013) and field-scale grass fires (Hilton et al. 2016), where it is shown that the inclusion of curvature dependence in a simple model improves the predictions of the model. Thomas et al. (2017) used a coupled atmosphere-fire model, WRF-Fire (Coen et al. 2013), to model junction fires (Viegas et al. 2012; Raposo et al. 2018). They did not find a relationship between local fireline curvature and local rate of spread in the model output, but they noted that, if it exists, such a relationship is unlikely to be local and should be searched for in some kind of mean sense. We report on more comprehensive numerical experiments in which we search for such a relationship using WRF-Fire. We also make a preliminary comparison of some fire-spread simulations using WRF-Fire and the pyrogenic potential model (Hilton et al. 2018).

\section{WRF-Fire simulations of junction fires}

Thomas et al. (2017) compared the local curvature at a point on the fireline with the instantaneous rate of spread at that point; no relationship was found. However, pyroconvective processes driving fire-induced winds are not local, and the computation of fireline curvature is a discrete approximation which is susceptible to small-scale variability (noise). This is illustrated in the left-hand panel in Figure 1. To increase the scale of the analysis, we compute an average fireline curvature by forming centred, moving averages of the pointwise fireline curvature, the averaging window having length $2 r$ where $r$ is arc length. Figure 1 shows the results for $r=50 \mathrm{~m}$, and is typical of all averaging lengths considered. There does not appear to be a relationship between fireline curvature, averaged in this way, and rate of spread for the WRF-Fire modelled junction fires.

\section{WRF-Fire simulations of arc fires}

Another way of increasing the scale of the analysis is to consider the curvature and the rate of spread of some notion of a mean fireline. To do this, we model fires that are ignited along a circular arc. At least for a period of time, these fires continue to burn in an approximately circular arc with radius $r$ which decreases as the fire evolves. This provides a systematic way of defining average curvature, $1 / \mathrm{r}$, and average rate of spread, $-\mathrm{d} r / \mathrm{d} t$. Figure 2 shows the results for three configurations. In each panel the initial fireline has the same curvature, and in each case the curvature increases (becomes more negative) as the fire evolves. 

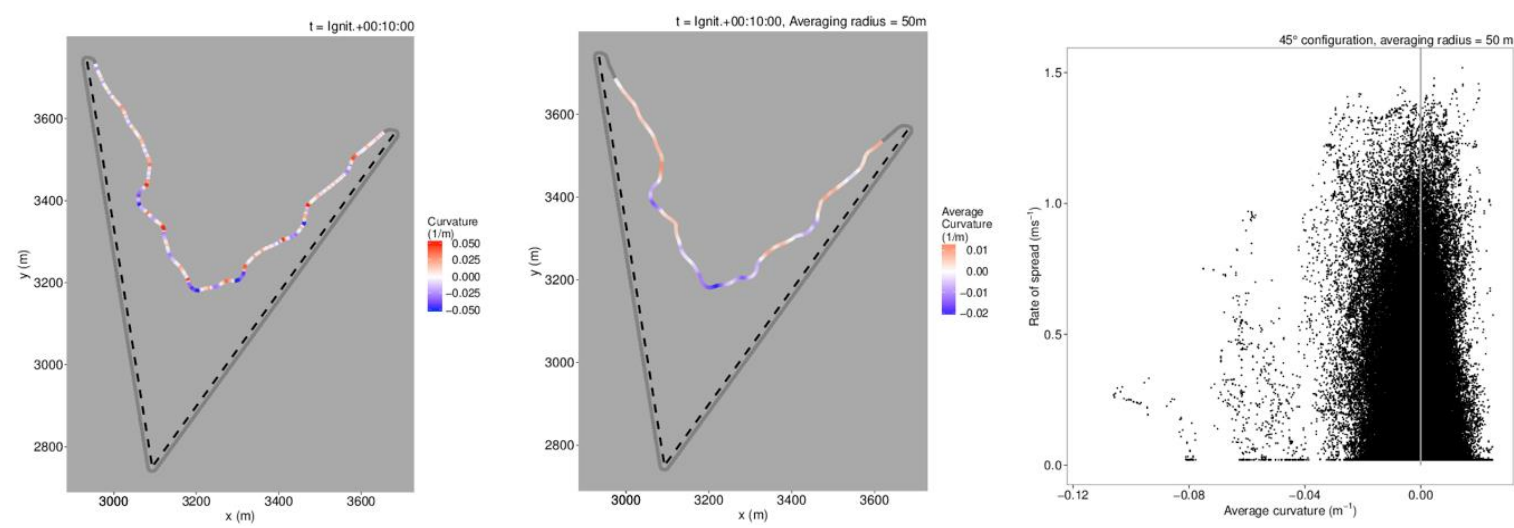

Figure 1 - Output of coupled atmosphere-fire model (WRF-Fire) for junction fires. Left panel: variability of pointwise fireline curvature in model output. Centre panel: average fireline curvature using 50 m radius moving window. Right panel: rate of spread versus average fireline curvature.

The distances between the isochrones indicate that the rate of spread increases with increasing length of initial arc, and does not increase as the fire evolves and the curvature increases.
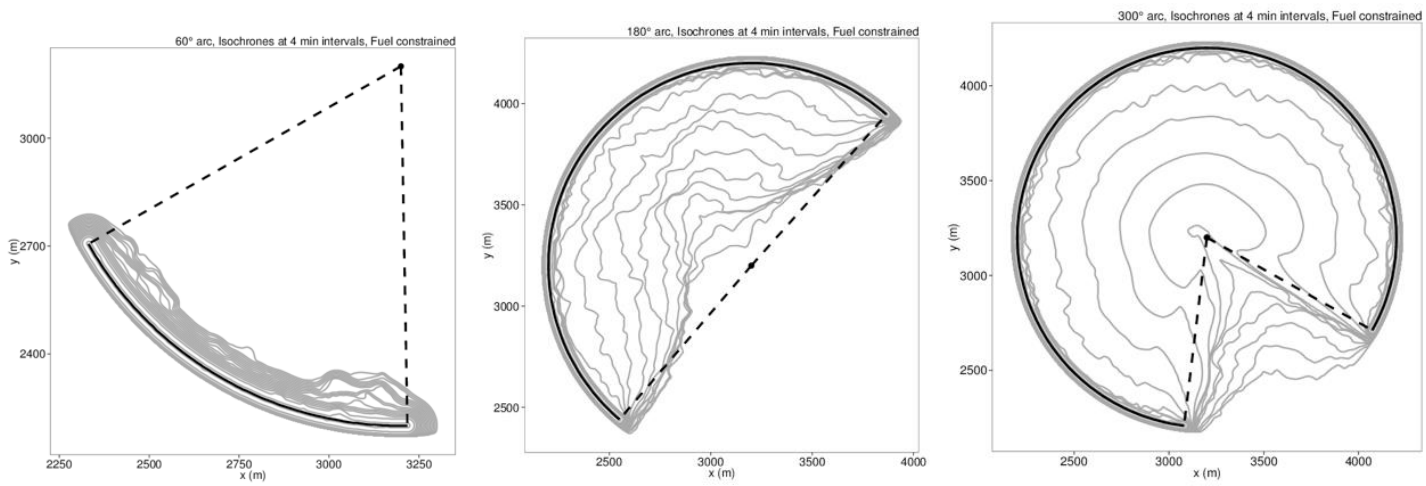

Figure 2 - Arc fire evolution simulated using WRF-Fire. Grey lines are isochrones at 4 minute intervals of simulated fires ignited along arcs of $60^{\circ}, 180^{\circ}$ and $300^{\circ}$, with radius $1000 \mathrm{~m}$. The distance between the isochrones indicates rate of spread.

\section{Comparison with arc fires modelled using pyrogenic potential}

Hilton et al. (2018) described a new model that simulates pyrogenically-induced bulk surface flow; the flow is assumed to be irrotational and divergence free, and when restricted to the surface can be described using Poisson's equation. Based on the assumption that surface winds are entrained into the plume, firelines represent sinks in the source term of the Poisson equation. The equation can be solved very efficiently, and the computed surface winds can be input into a fire-spread model, which then calculates fireline spread. The strength of the sinks are assumed to be related to fire intensity. This process can be iterated to provide a simple and very computationally efficient coupled model. Figure 3 shows isochrones at 4 minute intervals for preliminary modelling of arc fires using the pyrogenic potential model. It exhibits similar features to Figure 2. In particular, rates of spread increase with increased initial arc length, and do not increase with increasing curvature as the fireline evolves. 


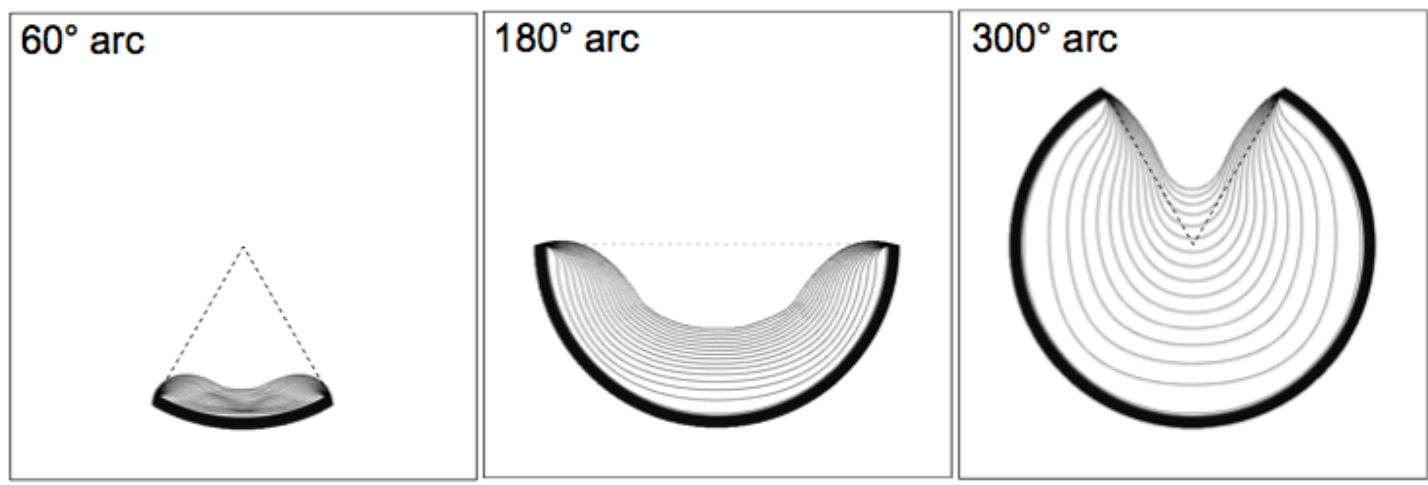

Figure 3 - Arc fire evolution simulated using the pyrogenic potential model. The lines are isochrones at 4 minute intervals.

\section{Conclusion}

Simulations of junction fires and arc fires using WRF-Fire do not indicate a relationship between fireline curvature and rate of spread at any scale. However, simulations of arc fires using WRF-Fire and the pyrogenic potential model exhibit similar features. This indicates the possibility that the results of a coupled atmosphere-fire model may be approximated, to first order, by a simple potential model. Future work may include comparison of these results with experiments, and exploration of the relationshipe between fire intensity and the strength of the sinks in the Poisson equation.

\section{References}

Coen, Janice L, Marques Cameron, John Michalakes, Edward G Patton, Philip J Riggan, and Kara M Yedinak. 2013. "WRF-Fire: Coupled Weather-Wildland Fire Modeling with the Weather Research and Forecasting Model." Journal of Applied Meteorology and Climatology 52 (1): 16-38. https://doi.org/10.1175/JAMC-D-12-023.1.

Hilton, J. E., C. Miller, J. J. Sharples, and A. L. Sullivan. 2016. "Curvature Effects in the Dynamic Propagation of Wildfires." International Journal of Wildland Fire. https://doi.org/10.1071/WF16070.

Hilton, J. E., A. L. Sullivan, W. Swedosh, J. Sharples, and C. Thomas. 2018. "Incorporating Convective Feedback in Wildfire Simulations Using Pyrogenic Potential." Environmental Modelling \& Software 107 (September): 12-24. https://doi.org/10.1016/j.envsoft.2018.05.009.

Raposo, J. R., D. X. Viegas, X. Xie, M. Almeida, A. R. Figueiredo, L. Porto, and J. Sharples. 2018. "Analysis of the Physical Processes Associated with Junction Fires at Laboratory and Field Scales." International Journal of Wildland Fire 27 (1): 52-68. https://doi.org/10.1071/WF16173.

Sharples, J J, I N Towers, G Wheeler, V.-M. Wheeler, and McCoy. 2013. "Modelling Fire Line Merging Using Plane Curvature Flow." In 20th International Congress on Modelling and Simulation, edited by J Piantadosi, R S Anderssen, and J Boland, 256-62. Adelaide, Australia.

Thomas, C. M., J. J. Sharples, and J. P. Evans. 2017. "Modelling the Dynamic Behaviour of Junction Fires with a Coupled Atmosphere-Fire Model." International Journal of Wildland Fire 26 (4): 33144. https://doi.org/10.1071/WF16079.

Viegas, Domingos X, Jorge R Raposo, David A Davim, and Carlos G Rossa. 2012. "Study of the Jump Fire Produced by the Interaction of Two Oblique Fire Fronts. Part 1. Analytical Model and Validation with No-Slope Laboratory Experiments." International Journal of Wildland Fire 21: 843-56. 